\title{
Ultrastructure of the genital organs in interstitial polychaetes. III. Penes and ejaculatory ducts in Hesionides arenaria (Hesionidae)
}

\author{
W. Westheide \\ II. Zoologisches Institut der Universität Göttingen; Berliner Str. 28, \\ D-3400 Göttingen, Federal Republic of Germany
}

\begin{abstract}
The ejaculatory ducts of the two paired copulatory organs in the interstitial polychaete Hesionides arenaria are ciliated tubes, which open into simple, partly groove-like, non-stiffened penis papillae. The larger part of the ducts within the dorsal body wall is surrounded by circular muscle cells. Voluminous gland cell bodies lie between the pharynx-gut system and the body wall in the anterior part of the body; they extend anteriorly like long, thin necks, of which several are always united in prominent strands. Their distal ends are expanded and penetrate the ducts. Six different types of glands can be distinguished according to the ultrastructure of their secretory granules. They produce the sheath of the double spermatophore or probably contain lytic enzymes that provide for the penetration of sperm into the body of the female. Differences in ultrastructure of the male organs in the interstitial genera Hesionides and Microphthalmus do not support the recent erection of the subfamily "Microphthalminae".
\end{abstract}

\section{INTRODUCTION}

Interstitial Polychaeta possess specific copulatory organs facilitating the direct transfer of sperm on or into the female partner. This method of reproduction ensures the fertilization of many or all the oocytes and reduces the problem related to the small number of female gametes produced (Westheide, 1983). Males of the biotope-typical genus Hesionides have a paired system of ejaculatory organs for the formation and transfer of spermatophores or naked sperm bundles (Westheide, 1967, 1970). The ultrastructural analysis of these organs is part of a series of studies on genital organs of interstitial polychaetes (Westheide, 1978, 1979a, 1979b, 1983), which above all will help to elucidate their functional morphology.

\section{MATERIAL AND METHODS}

Three mature male Hesionides arenaria Friedrich (Hesionidae), which were collected in the intertidal area of a sandy beach on the North Sea Island of Sylt, were fixed in a mixture of picric acid - paraformaldehyde - glutaraldehyde (see Westheide \& Rieger, 1978). They were embedded in an Araldite-Epon resin, cut using diamond knives on a Reichert Ultracut, and stained with uranylacetate and lead citrate. Photographs were taken with a Zeiss EM 10. 


\section{RESULTS}

The paired ejaculatory ducts begin at the seminal vesicles in the fourth setigerous segment extending ventrally and then bending in the fifth setigerous segment towards the dorsal side of the animal (Fig. 1). There the ducts run parallel to each other in the opposite direction until they reach the prostomium. Here each enters a penis papilla either to the right or to the left of the unpaired median tentacle on the prostomium. Further light microscopic details given in Westheide (1967).

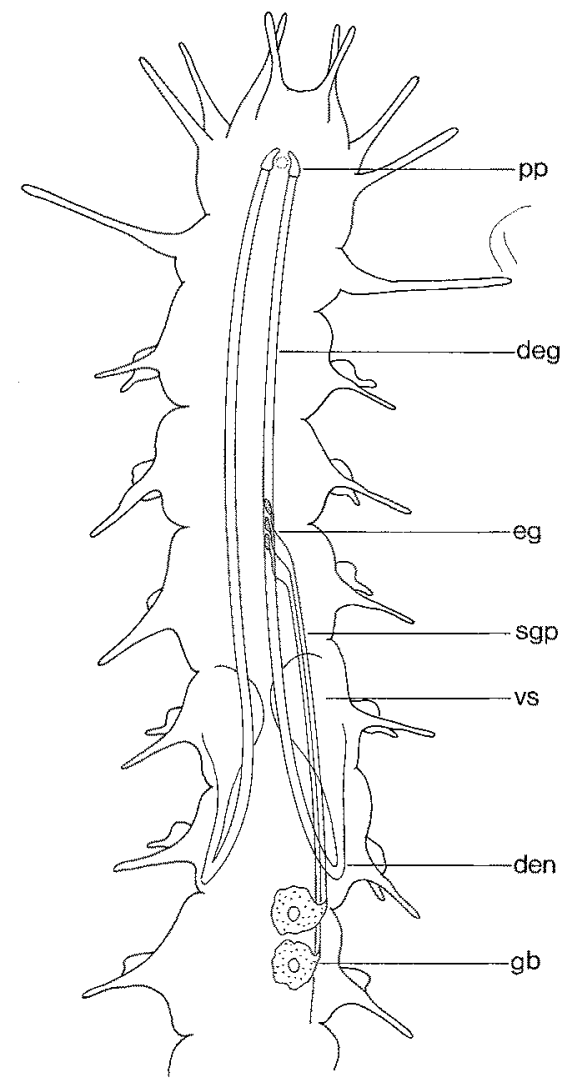

Fig. 1. Scheme of the male copulatory organs in Hesionides arenaria. deg - glandular part of the ejaculatory duct; den - non-glandular part of the ejaculatory duct ${ }_{i}$ eg - expanded ends of the gland cell projections inside the duct; gb - gland cell body; pp - penis papilla; sgp - strand of gland cell projections; vs - seminal vesicle

The tube-like ducts coming from the vesicles (diameter ca $2 \mu \mathrm{m}$ ) usually show in cross-sections one very flat cell that surrounds the lumen and whose ends are deeply interdigitated. Microvilli and cilia (up to 30 on a cross-section) project into the lumen. The part of the duct which turns towards the dorsal side of the animal, lies between the epidermis and the circular muscle layer of the body wall. The following glandular part (ductus glandularis), leading to the front and in cross-sections more or less oval, 

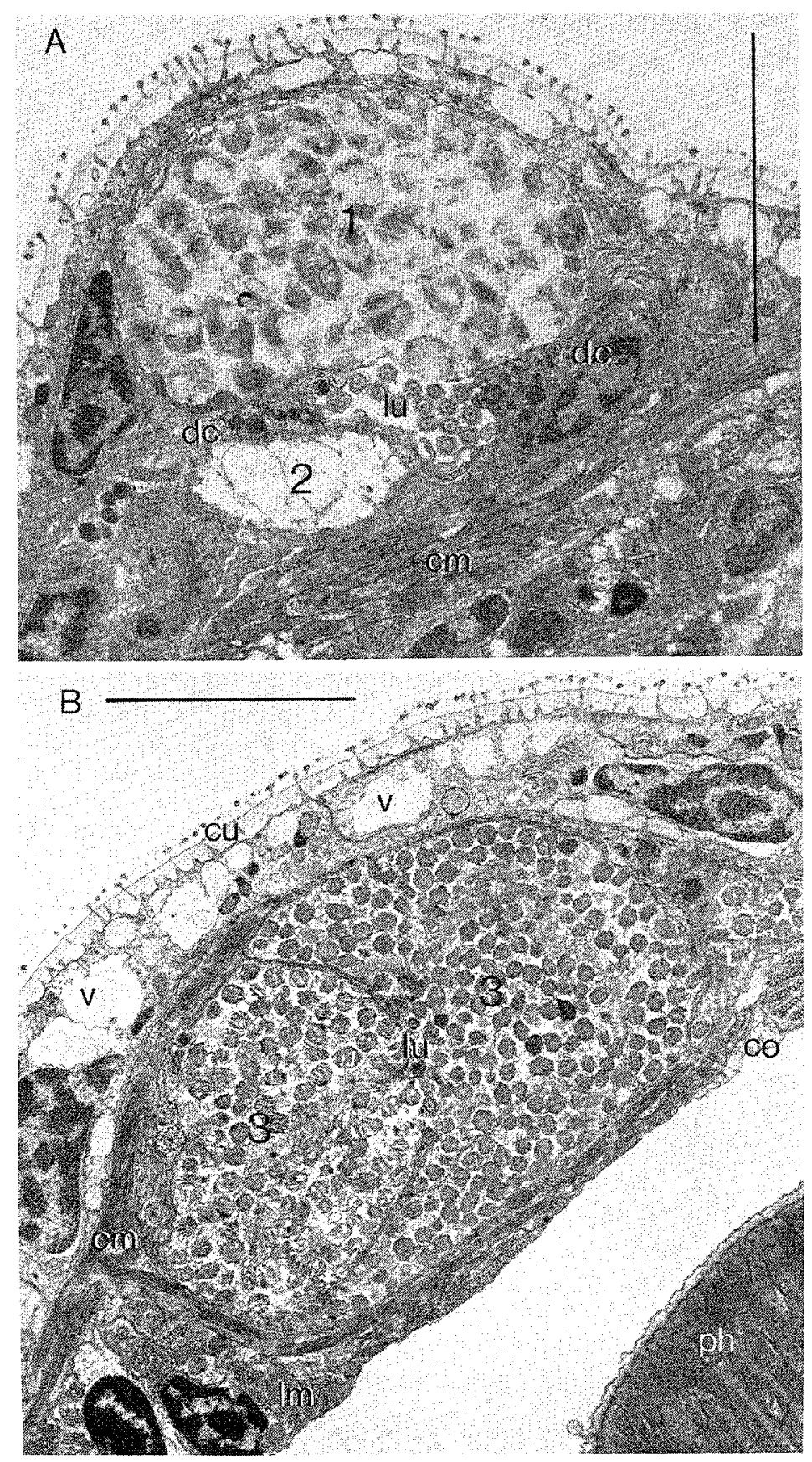

Fig. 2. Cross sections of the glandular part of the ejaculatory duct. (A) Region directly behind the penis papilla with secretory granules of Type 1 and Type 2. No circular muscles surround the duct dorsally in this region. Scale: $4 \mu \mathrm{m}$. (B) Middle region of the glandular part of the ejaculatory duct with Type 3 secretory granules. Scale: $5 \mu \mathrm{m}$. cm - circular muscle; cu - cuticle; co - cell lining the coelom; dc - ductus cell proper; $1 \mathrm{~m}$ - longitudinal muscle; lu - lumen of the duct with cilia; ph pharynx; v - epidermal vacuole (chordoid epidermal tissue) 

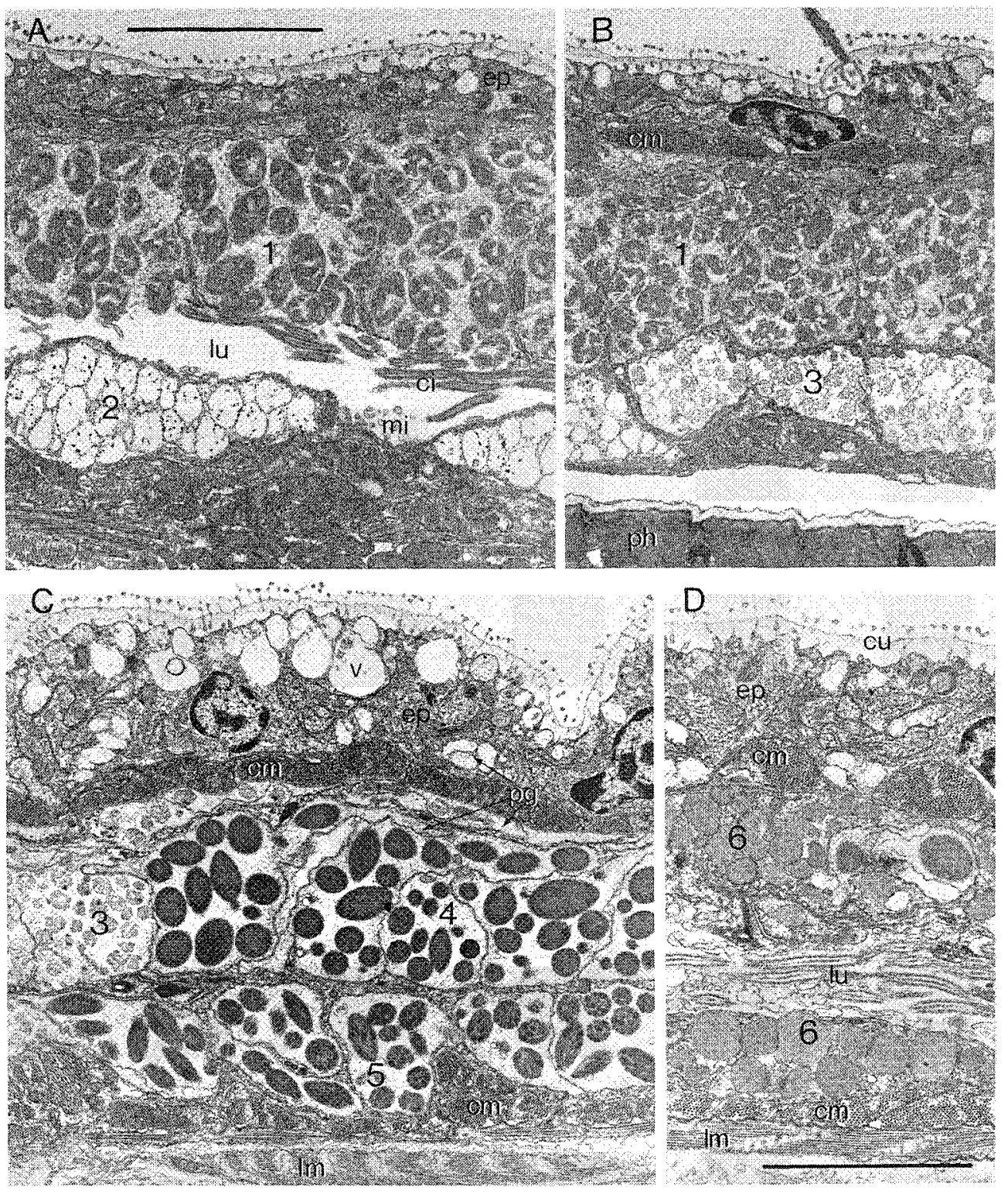

Fig. 3. Parasagittal and sagittal sections of the glandular part of the ejaculatory duct. Series of photos from the anterior region behind the penis papilla $(A)$ to the posterior region in the 4th setigerous segment (D). Same scale for A-C: $5 \mu \mathrm{m}$; D: $4 \mu \mathrm{m}$. 1-6: club-shaped ends of the gland projections inside the duct with different types of secretory granules (see text); $\mathrm{cm}$ - circular muscles of the body wall; cu - cuticle of the dorsal body surface; ep - epidermis cell; Im longitudinal muscles; lu - lumen of the duct with cilia (ci) and microvilli (mi); ph - pharynx; pg projections of the gland cells outside and inside the duct; $\mathrm{v}$ - epidermal vacuole 
penetrates this circular muscle layer. This happens through the partitioning of the fibril bundles of the individual circular muscle cells (Figs 2 B, 4). One part of this muscle layer is located under the duct and the other reaches dorsally. Several sections of the duct are not completely surrounded by these muscles, e.g. the dorsomedian part (Figs 2 B, 4). Further, the distal parts of these muscles do not form a closed sheath dorsally along the entire lenght (Fig. 2 D). Thus the glandular duct is more or less like a tube-formed basket, made out of circular muscles and often open at the top. Between the muscle cells and the epidermis, and also between the muscle cells and the duct cells proper there is a very thin basal lamina (Fig. 4). From the fourth setigerous segment to the penis papillae, the necks of gland cells penetrate laterally or dorsolaterally into the ducts. First they course along the two lateral sides of the ducts, then their ends expand like clubs bending towards the duct lumen (Fig. 1). As a result the duct cells proper are pressed together and are recognized only as a thin layer on the duct walls and around the lumen (Figs 2,4 ). The lumen itself is squashed to form a slit; it contains few (4-10) cilia. Light microscopic squash preparations show the ducts to have a fish-bone-like pattern due to the glandular protrusions.

The rounded cell bodies (diameter ca $15-20 \mu \mathrm{m}$ ) belonging to the glands are closely packed along both sides of the gut, up to the ninth setigerous segment. Their large nuclei, usually positioned centrally, are surrounded by well-developed and often distended cisternae of rough endoplasmic reticulum, numerous spherical golgi complexes (diameter ca $1.7 \mu \mathrm{m}$ ) and by the secretory granules that the latter have produced (Fig. 5). The transport of the granules into the ejaculatory ducts takes place in the "axon-like" necks mentioned above (Figs 5 B-D). These gland cell projections have a diameter of 0.2-0.4 $\mu \mathrm{m}$ and are significantly larger only where transported secretory granules (Figs 5 $C, D)$ are present. Several of these projections always run parallel, united like strands in a nerve-cord.

The fine structure shows at least six distinguishable types of membrane-bound granules, which form an equal number of distinct regions within the glandular parts of the ejaculatory ducts: the anterior section (directly behind the penis papillae) contains

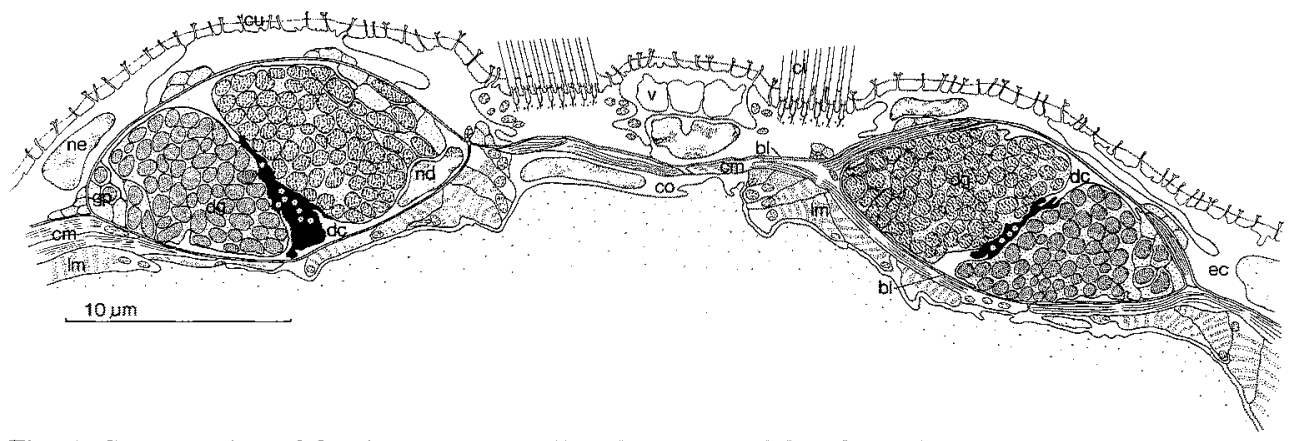

Fig. 4. Cross section of the dorsal body wall in the region of the glandular part of the two ejaculatory ducts. Slightly schematic. Black: lumen of the ejaculatory ducts, with cross sections of cilia. bl basal lamina; ci - bundle of cilia on the dorsal surface; co - cell lining the coelom; cm - circular muscle cell; cu - cuticle; dc - ductus cell proper; $\mathrm{dg}$ - distal end of cell projection coming from a genital gland cell, with specific secretory granules; ec - epidermis cell; gp - cell projections of genital gland cells within the duct; Im - longitudinal muscle cell; ne - nucleus of epidermis cell; nd - nucleus of ductus cell proper; $v$ - vacuole in epidermis cell (chordoid epidermal tissue) 
ovoid granules (diameter ca $1 \mu \mathrm{m}$ ) above the lumen, with flaky light and grey contents; the grey part has characteristic bowl-shaped structures (Type 1) (Figs $3 \mathrm{~A}, \mathrm{~B}, 6 \mathrm{C}$ ). In the same section, on the ventral side of the duct, projections of other glands end, the granular contents of which are incompletely preserved, probably because of the specific fixation used (Type 2). Within the granular membrane only very small electron-dense grains can be seen (Fig. 3 A). In the following section, Type 3 granules (diameter ca
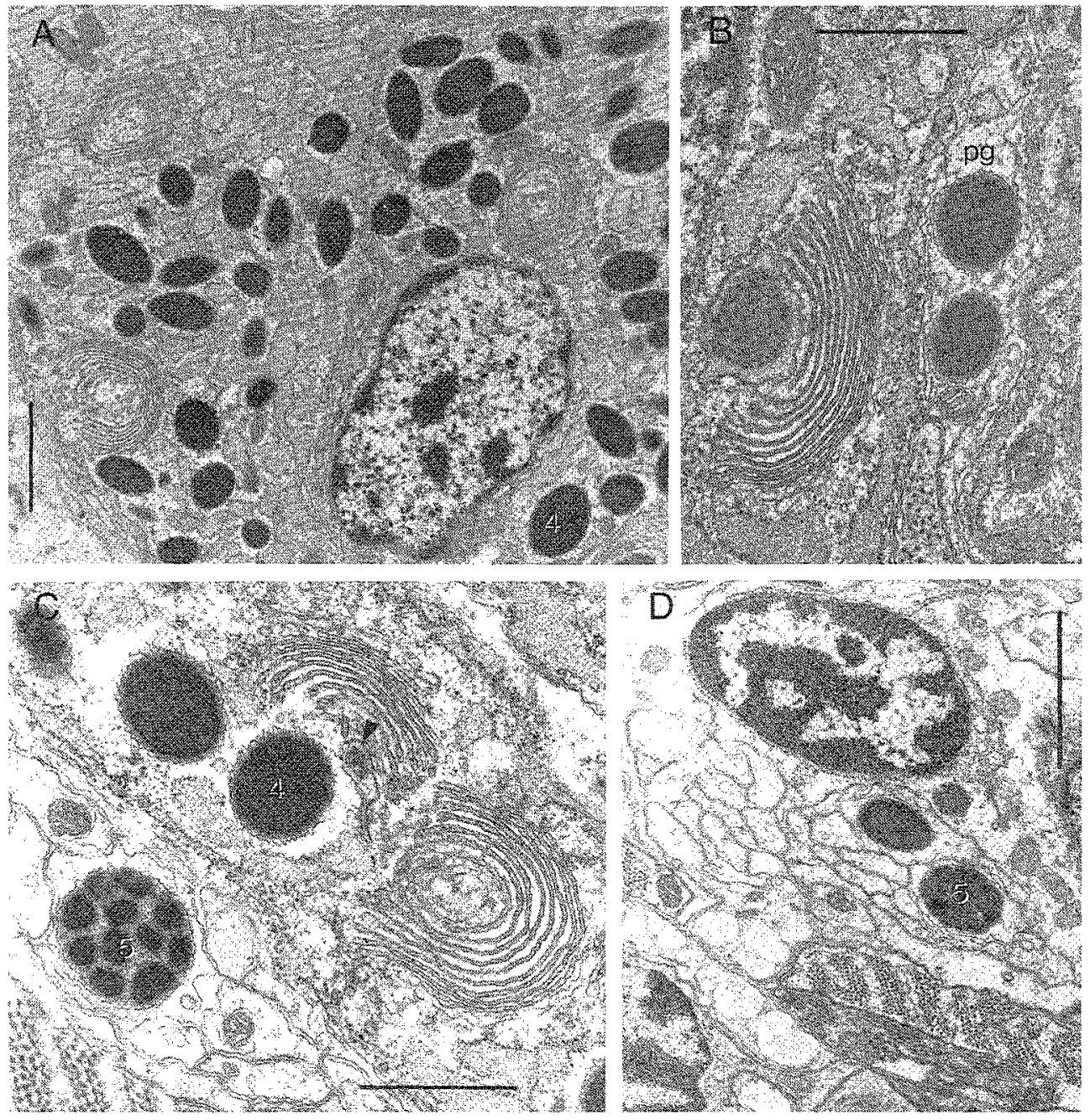

Fig. 5. (A) Gland cell producing Type 4 granules. Scale: $2 \mu \mathrm{m}$. (B) Golgi complex of a gland cell with a granule being formed in the centre. Right side: section of a gland cell projection (pg) with two migrating granules. Scale: $1 \mu \mathrm{m}$. (C) Below left: cross section of a strand of gland cell projections, one with a migrating Type 5 granule. Above right: part of gland cell body with Golgi complexes, granule in formation (arrow) and nearly completed granules of Type 4. Scale: $1 \mu \mathrm{m}$. (D) Cross sections of numerous projections of gland cells united into a prominent strand; two projections with migrating granules of Type 4 and 5. Scale: $2 \mu \mathrm{m}$ 
$0.5 \mu \mathrm{m}$ ) occur, at first only ventrally from the lumen, below the Type 1 cells, and then also dorsally. They contain very fine thread-like structures which form bundles (Figs $2 \mathrm{~B}, 3 \mathrm{~B}$, C). Following this, there are two more types of secretory structures lying opposite each other. Type 4 granules are spindle-shaped (ca $2 \mu \mathrm{m}$ long, ca $1.5 \mu \mathrm{m}$ wide), and have a

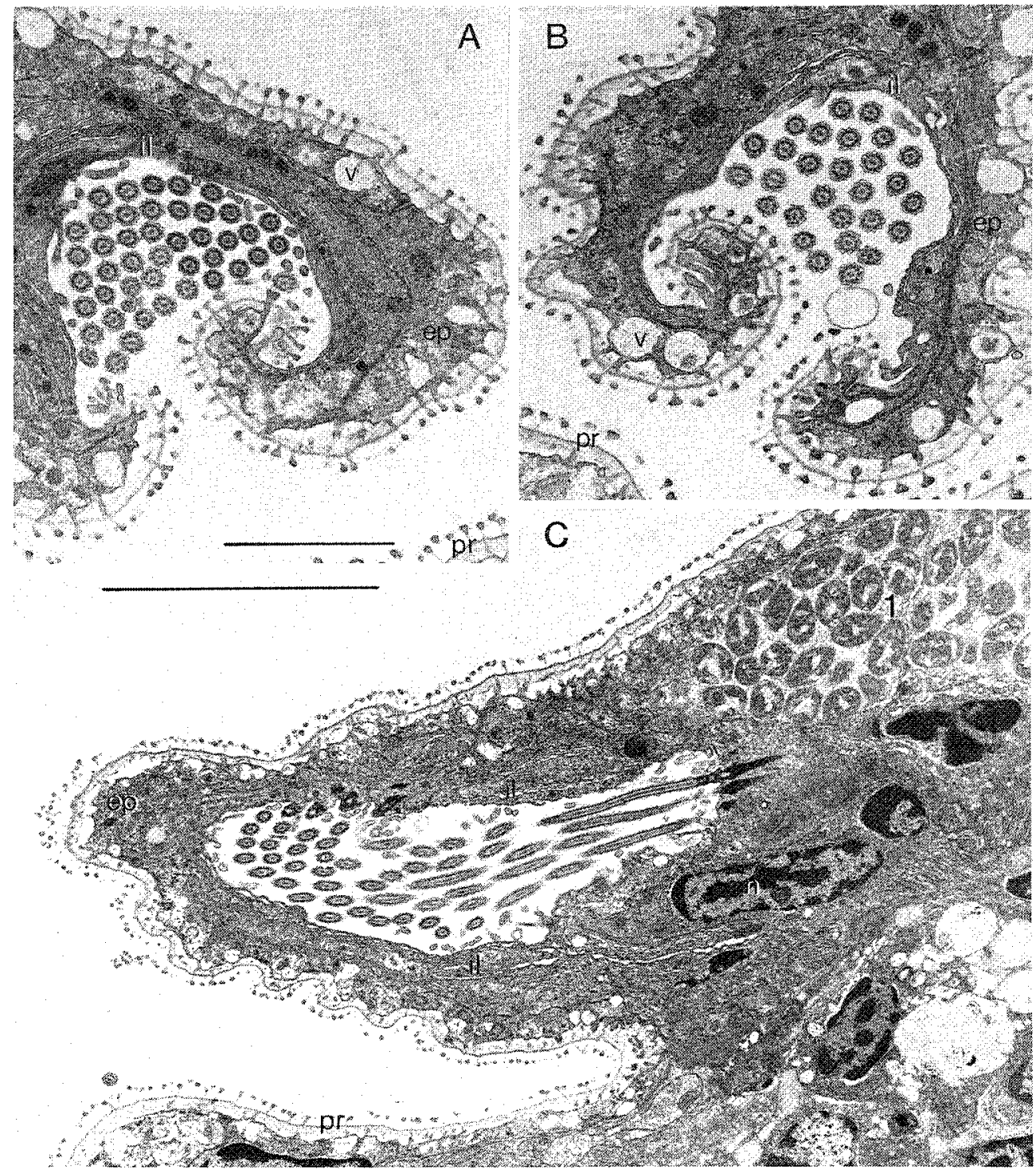

Fig. 6. Penis papilla $(A, B)$ Cross sections of the distal part with open ventral side. Lumen with a few microvilli and numerous cilia. Scale: $2 \mu \mathrm{m}$. (C) Sagittal section of a penis papilla and beginning of the glandular part of the duct. Papilla is slightly bent and therefore has not been cut along its total length. Scale: $5 \mu \mathrm{m}$. ep - epidermal layer of the papilla; il - duct cells with many-layered projections forming the inner layer of the papilla; $\mathrm{n}$ - nucleus of duct cell; $\mathrm{v}$ - epidermal vacuoles; 
homogenous electron-dense content with a narrow slightly lighter border region (Figs $3 \mathrm{C}, 5$ ). Type 5 granules are also spindleshaped (ca $1.5 \mu \mathrm{m}$ long, ca $0.8 \mu \mathrm{m}$ wide), but contain ten to twenty rods bound in parallel bundles. The rods have a grey appearance and each contains a dark electron-dense area (Figs 3 C, 5 C, D). Finally, Type 6 granules are positioned on both sides of the duct lumen. With their homogeneous grey content they strongly resemble Type 4 , but are rounded and irregular in size (ca $0.3 \mu \mathrm{m}$ ) (Fig. $3 \mathrm{D})$. The granular compartments of the latter cell projections are less extensive within the ducts, allowing more space for the duct cells proper and do not necessarily border on each other. Here the duct lumen is still very wide (ca $1.8 \mu \mathrm{m})$ and densely packed with cilia.

Under the light microscope, the penes look like conical papillae; they have a length of $20-30 \mu \mathrm{m}$; their base has a width of $6-8 \mu \mathrm{m}$, becoming narrower at the tip. Their cross sectional profile is approximately triangular with an open ventral side in the distal half lying on the prostomium (Figs $6 \mathrm{~A}, \mathrm{~B}$ ). The edges of this ventral side are rolled up in the lumen. The latter (ca $3 \mu \mathrm{m}$ wide) is filled by a bundle of cilia (ca 45 ), belonging to the duct cells at the bases of the penes (Fig. $6 \mathrm{C}$ ). Thus these copulatory organs resemble upside-down ciliated spouts. The outside covering consists of a relatively thin epidermal layer with small intracellular vacuoles ("chordoid tissue", see $\mathrm{Ax}, 1966$; Westheide, 1967), microvilli and a cuticle which is structurally indistinguishable from the neighbouring epidermal region on the dorsal side (see Westheide \& Rieger, 1978). The inner layer of the penis wall is formed by the duct cells that interdigitate with very flat (some thinner than $40 \mathrm{~nm}$ ), many-layered projections, meshed also with the epidermal cells (Fig. 6). The nuclei of the epidermis cells and the duct cells lie at the base or even further away, because there is not space enough within the penis.

\section{DISCUSSION}

The process of attaching the double spermatophores onto the skin of the sexual partner can take place within seconds and lasts at most a few minutes (Westheide \& Ax, 1965; Westheide, 1967). The formation of the irregularly-shaped and very simple sheaths of the spermatophores obviously takes place immediately before transfer. Spermatozoa were observed only seldom in the ducts, and fully developed spermatophores could never be found in squash preparations or histological sections. The two sperm bundles in a double spermatophore are probably rapidly pushed through the ejaculatory duct and at the same time are surrounded by a sheath while passing the glandular projections.

From these ultrastructural investigations, it is apparent that the cilia are the important structures for sperm transport from the seminal vesicles to the non-glandular part of the duct; contractions of the whole body, observed in males during transfer, probably aid this process. Contractions of the circular muscles surrounding the duct ventrally and dorsolaterally are then responsible for the transport within the glandular part of the duct and also for the ejection of the spermatophore itself. The cilia in this area, fewer in number and anteriorly directed, probably serve as valves preventing the sperm from slipping backwards. The voluminous bundle of the cilia in the penial organ may be responsible for the final release of the spermatophore from the duct, or the cilia, in conjunction with the grooved part, may finally form and smooth the spermatophore surface. 
The ultrastructural analysis shows that the glandular compartments within the duct are not complete specific cells, but only the distal ends of very long cell projections. Their corresponding cell bodies serving in the production of the secretory products, are the "accessory sex glands" from earlier light microscopic studies (Westheide, 1967). Because of their large volumes, these cell bodies do not have sufficient space in the direct surrounding of the ducts and are therefore positioned in a considerable number of segments between pharynx-gut and body wall. From the arrangement of the distal parts of the gland cells, one can conclude in which order the sperm passing through the duct comes in contact with the different secretions. Similar to spermatophore production of the leech Glossiphonia complanata (Damas, 1966, 1968a, b), the granules in the distal duct sections may provide lytic enzymes and the spermatophore sheath; the granules lying further back may contain active metabolites and enzymes and mingle with the sperm within the spermatophore.

The male copulatory system of Hesionides arenaria can be divided into different functional areas: the seminal vesicle for collection and storage of sperm; the moderately ciliated non-glandular duct section; the slightly ciliated glandular duct section that is controlled by circular muscles; the gland cell bodies externally positioned; the penial organs. These structures are ordered in the same sequence as in the copulatory organs of many other interstitial polychaetes - a similarity that is possibly due to the convergently evolved transformation out of segmental organs. This is also true for the male organs of the hesionid genus Microphthalmus. Course and location of the ducts, however, are different from the Hesionides species (Westheide, 1967), and also the fine structure, despite a large number of close similarities, shows characteristic and fundamental differences: e.g. in $M$. cf. listensis, the largest portion of the duct system, including the vesicle, is surrounded by longitudinal muscle cells not belonging to the body wall muscles (Westheide, 1983). But at the time of sexual maturity, this musculature is formed of cells from the paremchyme-like area between the gut and the body wall.

Thus the ultrastructural analysis of the male genital organs does not favour a sister group relationship of Hesionides and Microphthalmus, implied by the erection of the subfamily Microphthalminae by Hartmann-Schröder (1971). A more final clarification of the systematic position of the two genera may be brought about by an ultrastructure analysis of the characteristic anal lobes. This organ appears to be their only synapomorphic feature. Similar adhesive organs, however, are also observed in other interstitial polychaete taxa not closely related to each other. They may therefore also be convergently evolved in Hesionides and Microphthalmus.

Acknowledgments. I wish to thank Prof. Dr. N. W. Riser for assistance in translation, D. Bürger and M. Frixe for technical assistance. The investigation was supported by the Deutsche Forschungsgemeinschaft and the Akademie der Wissenschaften und der Literatur, Mainz (Arbeitsstelle zur Erforschung der Mikrofauna des Meeresbodens in Göttingen, Prof. Dr. Peter Ax).

\section{LITERATURE CITED}

Ax, P., 1966. Das chordoide Gewebe als histologisches Lebensformmerkmal der Sandlückenfauna des Meeres. - Naturw. Rdsch., Stuttg. 19, 282-289.

Damas, D., 1966. Anatomie et histologie des canaux éjaculateurs de Glossiphonia complanata (L.) (Hirudinée Rhynchobdelle). - Archs Zool. exp. gén. 107, 325-336. 
Damas, D., 1968a. Origine et structure du spermatophore de Glossiphonia complanata (L.) (Hirudinée, rhynchobdelle). - Archs Zool. exp. gén. 109, 79-85.

Damas, D., 1968b. Histochimie des canaux ejaculateurs de Glossiphonia complanata (L.) (Hirudinée, rhynchobdelle) - Annls Histochim. 13, 111-122.

Hartmann-Schröder, G., 1971. Annelida, Borstenwürmer, Polychaeta. - Tierwelt Dt1. 58, $1-594$.

Westheide, W., 1967. Monographie der Gattungen Hesionides Friedrich und Microphthalmus Mecznikow (Polychaeta). Ein Beitrag zur Organisation und Biologie psammobionter Polychaeten. - Z. Morph. Tiere 61, 1-159.

Westheide, W., 1970. Zur Organisation, Biologie und Ókologie des interstitiellen Polychaeten Hesionides gohari Hartmann-Schröder (Hesionidae). - Mikrofauna Meeresboden 3, 1-37.

Westheide, W., 1978. Ultrastructure of the genital organs in interstitial polychaetes. I. Structure, development and function of the copulatory stylets in Microphthalmus cf. listensis. - Zoomorphologie 91, 101-108.

Westheide, W., 1979a. Ultrastruktur der Genitalorgane interstitieller Polychaeten. II. Intrazelluläre Stilettorgane in einer Microphthalmus-Art. - Zool. Scr. 8, 111-118.

Westheide, W., 1979b. Unusual granules in the ejaculatory duct of a Microphthalmus species (Polychaeta, Annelida). - Cell Tiss. Res. 197, 262-270.

Westheide, W., 1983. The concept of reproduction in polychaetes with small body size: Adaptation in interstitial species. - Fortschr. Zool. (In press).

Westheide, W. \& Ax, P., 1965. Bildung und Ubertragung von Spermatophoren bei Polychaeten (Untersuchungen an Hesionides arenarius Friedrich). - Zool. Anz. (Suppl.) 28, 196-203.

Westheide, W. \& Rieger, R, M., 1978. Cuticle ultrastructure of hesionid polychaetes. - Zoomorphologie 91, 1-18. 